\title{
Radiotherapy in the treatment of Graves ophthalmopathy — to do it or not?
}

\author{
Aneta Zygulska
}

Received: 14 January 2009/Accepted: 13 April 2009/Published online: 6 October 2009

(C) The Author(s) 2009. This article is published with open access at Springerlink.com

\begin{abstract}
To the objective of this study is to evaluate the role and toxicity of radiotherapy in the treatment of Graves ophthalmopathy. In the years 2000-2003, 121 patients with malignant exophthalmos were treated with radiotherapy of the retrobulbar area to the total dose of $20 \mathrm{~Gy}$ in ten fractions with a $6 \mathrm{MeV}$ photon beam. The treatment was performed by the team of the Clinic of Oncology of the Jagiellonian University Medical College in Cracow. The radiotherapy was preceded by intravenous steroid therapy: methylprednisolone acetate administered at the dose of $2 \mathrm{~g} /$ week for four consecutive weeks. The highest efficacy, expressed as improvement of all ocular symptoms, was observed for the combined treatment. Female and non-diabetic patients responded positively to the combined treatment. Radiotherapy combined with steroid therapy in the treatment of Graves ophthalmopathy seems to be an effective treatment for strictly defined indications. In the treatment of Graves-Basedow disease, radiotherapy is a welltolerated treatment modality. Diabetes is a factor that worsens prognosis in Graves ophthalmopathy and female sex is a favourable factor for this condition.
\end{abstract}

Keywords Graves ophthalmopathy · Radiotherapy · Combined treatment

\section{Introduction}

Graves ophthalmopathy is a complex of ocular symptoms accompanying autoimmune thyroid diseases. In $90 \%$ of cases, it is associated with hyperthyreosis. In the other $10 \%$ of

\footnotetext{
A. Zygulska $(\bowtie)$

Szpital Uniwersytecki,

Krakow, Poland

e-mail: zygulska@poczta.onet.pl
}

cases, it is diagnosed in euthyreotic patients, and is called ocular Graves disease, or in hypothyreotic patients (and then it is most frequently associated with Hashimoto disease) [40]. Modern imaging techniques revealed that ocular symptoms occur in almost all patients with hyperthyreosis $[11,12,69$, $73,74]$. These are usually benign lesions (non-infiltrative ophthalmopathy) that subside totally after normal thyroid function is restored $[11,18,49,70,73]$. About $5-10 \%$ of patients with hyperthyreosis develop Graves ophthalmopathy of a progressive course that may lead to severe ocular complications [28, 73, 74]. Sometimes only involvement of oculomotor muscles is found without exophthalmos. Optic neuropathy, corneal ulcerations and perforations with consequent blindness may occur [21, 28, 73, 74].

In the treatment of infiltrative ophthalmopathy, irrespective of thyroid function control, there is a necessity to reduce the volume of oedematous swollen intraorbital tissues to expand free space inside the orbit. To achieve the above glycocorticosteroid treatment, radiotherapy, combination of both methods or surgical orbital decompression are used [1, 7, 11, 35, $36,42,65,71,72,73]$. Surgical decompression reduces only mechanical effects of exophthalmos and usually, sooner or later, requires subsequent glycocorticosteroid therapy. Effectiveness of glycocorticosteroids (recently administered in the form of pulses of methylprednisolone acetate) is found to be $60 \%[11,37,58,64,73]$.

Starting from the year 1983, high doses of glycocorticosteroid are combined with orbital radiotherapy [5]. Glycocorticosteroid therapy provides quick improvement of ocular symptoms and prevents transient worsening of these symptoms as the result of radiotherapy [11, 16, 29, 42, 53, 67]. Irradiation consolidates the effects of steroid therapy and decreases the risk of ocular symptoms relapse [9, 11, 16, 57, 73]. Radiotherapy has unspecific antiinflammatory and specific immunosupressive effects on 
both mediators (lymphocytes) and effectors (fibroblasts) of the immune reaction in the orbit $[56,74]$. The optimal irradiation dose in the treatment of Graves ophthalmopathy is $20 \mathrm{~Gy}$ in ten fractions administered within 2 weeks [11, 27, 30, 31, 39, 56, 62, 73-75].

This paper summarizes my own experience in the treatment of Graves ophthalmopathy.

\section{Materials and methods}

From January 2000 to December 2003, the team of the Clinic of Oncology of the Jagiellonian University Medical College performed radiotherapy of the retrobulbar area in 121 patients (91 female-75.2\% and 30 males-24.8\%). Mean age was 55.1 years (range, 32-85). One hundred sixteen out of 121 (95.9\%) patients received previously in the Clinic of Endocrinology intravenous treatment with methylprednisolone acetate at the dose of $2 \mathrm{~g} / \mathrm{week}$ for four consecutive weeks.

Five patients $(4.1 \%)$ did not receive glycocorticosteroids due to: contraindications (two patients), improvement of ocular symptoms after treatment with methimazole (except persistent symptoms within the peribulbar soft tissue; two patients) and due to refusal of consent for steroid treatment (one patient).

Twelve months after the treatment was completed, in 106/ 121 patients ophthalmologic examination and orbital CT scan were performed. Three out of the remaining 15 patients died before the follow-up visit and 12 refused to undergo the follow-up procedures. Clinical characteristics of 101 patients subject to further analysis are presented in Table 1.

As shown in the table above, mean age in the combined treatment group was 52 years. Female patients, non-smokers and non-diabetics predominated. Mean time from the onset of ocular symptoms to the treatment start was 16 months. The majority of patients was previously treated for hyperthyreosis (61/101 i.e. $60.4 \%)$ and was hyperthyreotic at the time of exophthalmos onset. However, at the moment of referral for radiotherapy, the majority of patients had normal fT4 and thyroid-stimulating hormone (TSH) levels.

The subsequent analysis will involve two groups of patients:

1. One hundred one101 patients previously treated with intravenous steroids (assessed before radiotherapy),

2. Ninety-three patients out of 101 patients in group A treated with the combined method, i.e., with steroid therapy with subsequent radiotherapy to the total dose of $20 \mathrm{~Gy}$ in ten fractions (assessed after radiotherapy).

Irradiation technique

Before the start of radiotherapy assessed individual celone moulds were done for all patients. In all patients, orbital CT
Table 1 Characteristics of 101 patients treated with the combined method

\begin{tabular}{|c|c|c|}
\hline Mean age & 52.3 & 3 years $(32-81)$ \\
\hline \multicolumn{3}{|l|}{ Sex } \\
\hline Males & & $26(25.7 \%)$ \\
\hline Females & & $75(74.3 \%)$ \\
\hline $\begin{array}{l}\text { Time from the onset of ocular } \\
\text { symptoms to the start of } \\
\text { the combined treatment } \\
\text { Smoking }\end{array}$ & 16.8 & months (4-116 months) \\
\hline No & & $50(49.5 \%)$ \\
\hline Yes & & $49(48.5 \%)$ \\
\hline Unknown & & $2(2 \%)$ \\
\hline \multicolumn{3}{|l|}{ Diabetes } \\
\hline No & & $89(88.1 \%)$ \\
\hline Yes & & $12(11.9 \%)$ \\
\hline \multicolumn{3}{|l|}{$\begin{array}{l}\text { Thyroid status at the moment } \\
\text { of exophthalmos diagnosis }\end{array}$} \\
\hline Normal & & $16(15.8 \%)$ \\
\hline Hyperthyreosis & & $74(73.3 \%)$ \\
\hline Unknown & & $11(10.9 \%)$ \\
\hline \multicolumn{3}{|l|}{ Treatment of hyperthyreosis } \\
\hline No & & $17(16.8 \%)$ \\
\hline Yes & & $84(83.2 \%)$ \\
\hline \multicolumn{3}{|l|}{$\begin{array}{l}\text { Pre-treatment fT4 level } \\
\text { (normal range, } 11-22 \mathrm{pmol} / \mathrm{l} \text { ) }\end{array}$} \\
\hline Normal & & $74(73.3 \%)$ \\
\hline Elevated & & $5(5 \%)$ \\
\hline Lowered & & $16(15.8 \%)$ \\
\hline No data & & $6(5.9 \%)$ \\
\hline \multicolumn{3}{|l|}{$\begin{array}{l}\text { Pre-treatment TSH level: } \\
\text { (normal range, } 0.2-6.5 \mu \mathrm{U} / \mathrm{mol} \text { ) }\end{array}$} \\
\hline Normal & & $70(69.3 \%)$ \\
\hline Elevated & & $7(6.9 \%)$ \\
\hline Lowered & & $24(23.8 \%)$ \\
\hline
\end{tabular}

scans were done for treatment planning. CT slice thickness was $3 \mathrm{~mm}$. Two opposite isocentric beam techniques were used to cover the retrobulbar area. Beam angles were adjusted for divergence to form coincident plane behind lenses (Fig. 1). Extraorbital structures were individually shielded with Wood alloy shields. Irradiation was performed with a $6 \mathrm{MeV}$ photon beam emitted by the Mevatron Primus accelerator. The planned irradiation dose was $20 \mathrm{~Gy}$ in ten fractions. Treatment planning was done in a 3D treatment planning system-TMS Helax.

Assessment of treatment efficacy

The following methods were used to assess the efficacy of the treatment: medical history, ophthalmologic examination and CT scan of the retrobulbar areas. Ophthalmologic examination was done before the start of the treatment and 


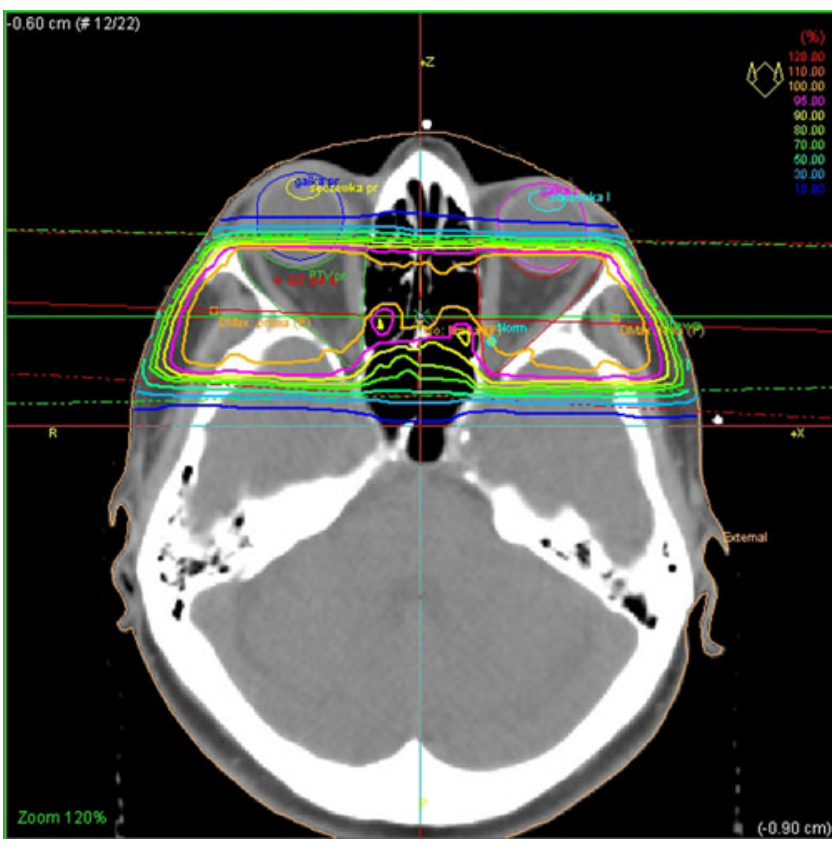

Fig. 1 The arrangement of beams and the dose distribution during irradiation of the retrobulbar area in Graves-Basedow disease

12 months after treatment completion. During the examination the NOSPECT score system was used to define severity of ophthalmopathy based on such parameters as: soft tissues (i.e., conjunctiva, eyelids), exophthalmos, oculomotor muscle dysfunction, condition of the cornea and vision. These symptoms were attributed scores: $1-2-3$, depending on symptom severity. Eyelids and conjunctiva: 1 - minor reddening of conjunctiva or moderate eyelid oedema, 2-significant reddening of conjunctiva or major eyelid oedema, 3-severe inflammatory condition of the above structures. Exophthalmos was measured with exophthalmometer: 20-24 mm scored-1, 24-27 mm-2, above $27 \mathrm{~mm}-3$. Oculomotor muscle involvement: eye globe mobility impairment in extreme eye positions - 1 , significant impairment of eye globe mobility-2, immobilisation of one or both eye globes-3. Cornea: single epithelial defects (with fluorescein staining) - 1 , moderate epithelial defects-2, extensive epithelial defects-3. Snellen chart was used for vision assessment. Vision defect ranging from $0.67-0.33$ scored $1,0.32-0.10-2$, below $0.10-3$. CT scan of retrobulbar areas was performed in all patients before the start the treatment and after 12 months of treatment completion. Based on CT of retrobulbar area the following parameters were assessed: thickness of the recti muscles and lacrimal glands, volume of the retrobulbar fat and optic nerve condition.

\section{Statistical analysis}

Qualitative parameters were characterised by percentage distribution. Relationships between qualitative parameters, including assessment of the treatment effect, were evaluated with chi square independent test. To compare particular treatment stages the case-control method and Fisher test was used. $p$ value was calculated for all tests.

\section{Results}

Evaluation of the treatment with steroids

Treatment results as assessed by ophthalmologic examination in the group of patients treated previously with intravenous steroids (situation before radiotherapy) are presented in Tables 2 and 3.

Based on the above table, significant improvement within right peribulbar soft tissues following intravenous steroid therapy may be shown $(p<0.05)$. Nevertheless, this observation is weakened by the fact that in half of the patients, post-treatment ophthalmologic assessment is missing.

Based on the above table, significant improvement within left peribulbar soft tissues following intravenous steroid therapy may be shown $(p<0.05)$. Nevertheless, this observation is weakened by the fact that in half of the patients, post-treatment ophthalmologic assessment is missing.

Treatment results as assessed by computed tomography (CT) of the retrobulbar areas 12 months after treatment completion in the group of patients treated previously with intravenous steroid therapy.

Treatment results are presented in Table 4.

As shown in the table above, no improvement was found within the right eye as assessed with computed tomography. Only slight improvement of the left eye condition was observed, in terms of reduction of the retrobulbar fat tissue.

\section{Evaluation of efficacy of the combined treatment}

Treatment results as assessed by ophthalmologic examination.

The results are presented in Tables 5 and 6 .

Based on the table, no effect of intravenous steroid therapy followed by radiotherapy was found within the right eye, as assessed by ophthalmologic examination (no statistical significance).

Based on the table, no effect of intravenous steroid therapy followed by radiotherapy was found within the left eye, as assessed by ophthalmologic examination (no statistical significance).

Treatment results as assessed by computed tomography (CT) of the retrobulbar areas.

Treatment efficacy measured with CT of retrobulbar areas is presented in Table 7.

As shown in the table, no improvement was achieved within the right eye after the combined treatment, as assessed by computed tomography. Some improvement 
Table 2 Treatment results as assessed by ophthalmologic examination in the group of patients treated previously with intravenous steroids $(n=101)$ - the right eye

\begin{tabular}{|c|c|c|c|c|}
\hline & NOSPECT & The right eye before steroid treatment & The right eye after steroid treatment & $\mathrm{p}$ (Mc Nemara test) \\
\hline \multirow[t]{5}{*}{ Soft tissues } & Normal & $15 / 101(14.8 \%)$ & $15 / 42(35.7 \%)$ & 0.0059 \\
\hline & Grade 3 & $1 / 101(1.0 \%)$ & $0 / 42(0.0 \%)$ & 0.5165 \\
\hline & Grade 2 & $33 / 101(32.7 \%)$ & $0 / 42(0.0 \%)$ & \\
\hline & Grade 1 & $52 / 101(51.5 \%)$ & $27 / 42(64.3 \%)$ & \\
\hline & Not examined & $0 / 101(0.0 \%)$ & $59 / 101(58.4 \%)$ & \\
\hline \multirow[t]{5}{*}{ Exophthalmos } & Normal & $46 / 101(45.5 \%)$ & $18 / 42(42.8 \%)$ & 0.7678 \\
\hline & Grade 3 & $2 / 101(2.0 \%)$ & $1 / 42(2.4 \%)$ & 0.8799 \\
\hline & Grade 2 & $12 / 101(11.9 \%)$ & $5 / 42(11.9 \%)$ & \\
\hline & Grade 1 & $41 / 101(40.6 \%)$ & $18 / 42(42.8 \%)$ & \\
\hline & Not examined & $0 / 101(0.0 \%)$ & $59 / 101(58.4 \%)$ & \\
\hline \multirow[t]{5}{*}{ Oculomotor muscles } & Normal & $23 / 101(22.8 \%)$ & $12 / 42(28.6 \%)$ & 0.4639 \\
\hline & Grade 3 & $6 / 101(5.9 \%)$ & $0 / 42(0.0 \%)$ & 0.1101 \\
\hline & Grade 2 & $35 / 101(34.7 \%)$ & $11 / 42(26.2 \%)$ & \\
\hline & Grade 1 & $37 / 101(36.6 \%)$ & $19 / 42(45.2 \%)$ & \\
\hline & Not examined & $0 / 101(0.0 \%)$ & $59 / 101(58.4 \%)$ & \\
\hline \multirow[t]{5}{*}{ Cornea } & Normal & $88 / 101(87.2 \%)$ & $36 / 42(85.7 \%)$ & 0.8099 \\
\hline & Grade 3 & $0 / 101(0.0 \%)$ & $0 / 42(0.0 \%)$ & 1.0000 \\
\hline & Grade 2 & $0 / 101(0.0 \%)$ & $0 / 42(0.0 \%)$ & \\
\hline & Grade 1 & $13 / 101(12.8 \%)$ & $6 / 42(14.3 \%)$ & \\
\hline & Not examined & $0 / 101(0.0 \%)$ & $59 / 101(58.4 \%)$ & \\
\hline \multirow[t]{5}{*}{ Visual acuity } & Normal & 8/101 (7.9\%) & $1 / 42(2.4 \%)$ & 0.2191 \\
\hline & Grade 3 & $0 / 101(0.0 \%)$ & $0 / 42(0.0 \%)$ & 1.0000 \\
\hline & Grade 2 & $0 / 101(0.0 \%)$ & $0 / 42(0.0 \%)$ & \\
\hline & Grade 1 & $93 / 101(92.1 \%)$ & $41 / 42(97.6 \%)$ & \\
\hline & Not examined & $0 / 101(0.0 \%)$ & $59 / 101(58.4 \%)$ & \\
\hline
\end{tabular}

was achieved within the left eye in terms of fat tissue reduction and decrease of optic nerve oedema. However, this observation is based on a relatively small group of patients.

\section{Comparison of treatment results}

Improvement after the treatment of malignant exophthalmos was mostly of subjective nature. Therefore, evaluation of efficacy of particular treatment methods was limited to the patient self-reported results (Table 8).

As demonstrated in the table above, the highest efficacy with respect to improvement of all ocular symptoms was found after the combined treatment. Taking into consideration the fact that the combined treatment of ophthalmopathy was the most effective one, the effect of prognostic factors on the results of this treatment was studied. It was shown that females and non-diabetic patients respond favourably to the combined treatment (Tables 9 and 10). Such factors as patient age, ocular symptoms duration, smoking and thyroid function did not affect treatment results (no statistical significance was demonstrated).
Toxicity of radiotherapy

Acute reaction occurred in 11/121 patients (9.1\%) during radiotherapy. Symptoms of acute reactions are presented in Table 11.

Acute reaction symptoms were mild to moderate and transient. Acute reaction in the diabetic group was not worse than average.

During follow-up after treatment completion in the group of 106 patients, three cases of cataract were diagnosed that were rather related to physiological ageing process than to radiotherapy. No diabetic retinopathy was found in the diabetic group.

Symptoms of late post-irradiation reaction are presented in Table 12.

\section{Discussion}

Aetiology of ophthalmopathy is not fully understood; therefore, its treatment is usually of palliative nature and 
Table 3 Treatment results as assessed by ophthalmologic examination in the group of patients treated previously with intravenous steroids $(n=101)$ - the left eye

\begin{tabular}{|c|c|c|c|c|}
\hline & NOSPECT & The left eye before steroid treatment & The left eye after steroid treatment & $\mathrm{p}$ (Mc Nemara) \\
\hline \multirow[t]{5}{*}{ Soft tissues } & Normal & $14 / 101(13.8 \%)$ & $16 / 42(38.1 \%)$ & 0.0014 \\
\hline & Grade 3 & $1 / 101(1.0 \%)$ & $0 / 42(0.0 \%)$ & 0.5165 \\
\hline & Grade 2 & $32 / 101(31.7 \%)$ & $0 / 42(0.0 \%)$ & \\
\hline & Grade 1 & $54 / 101(53.5 \%)$ & $26 / 42(61.9 \%)$ & \\
\hline & Not examined & $0 / 101(0.0 \%)$ & $59 / 101(58.4 \%)$ & \\
\hline \multirow[t]{5}{*}{ Exophthalmos } & Normal & $54 / 101(53.5 \%)$ & $23 / 42(54.8 \%)$ & 0.8873 \\
\hline & Grade 3 & $4 / 101(3.9 \%)$ & $0 / 42(0.0 \%)$ & 0.1965 \\
\hline & Grade 2 & $12 / 101(11.9 \%)$ & $6 / 42(14.3 \%)$ & \\
\hline & Grade 1 & $31 / 101(30.7 \%)$ & $13 / 42(30.9 \%)$ & \\
\hline & Not examined & $0 / 101(0.0 \%)$ & $59 / 101(58.4 \%)$ & \\
\hline \multirow[t]{5}{*}{ Oculomotor muscles } & Normal & 15/101 (14.9\%) & $9 / 42(21.4 \%)$ & \\
\hline & Grade 3 & $5 / 101(4.9 \%)$ & $0 / 42(0.0 \%)$ & 0.3454 \\
\hline & Grade 2 & $37 / 101(36.6 \%)$ & $12 / 42(28.6 \%)$ & 0.1465 \\
\hline & Grade 1 & 44/101 (43.6\%) & $21 / 42(50.0 \%)$ & \\
\hline & Not examined & $0 / 101(0.0 \%)$ & $59 / 101(58.4 \%)$ & \\
\hline \multirow[t]{5}{*}{ Cornea } & Normal & $88 / 101(87.1 \%)$ & $33 / 42(78.6 \%)$ & 0.2017 \\
\hline & Grade 3 & $1 / 101(1.0 \%)$ & $0 / 42(0.0 \%)$ & 0.5165 \\
\hline & Grade 2 & $1 / 101(1.0 \%)$ & $0 / 42(0.0 \%)$ & \\
\hline & Grade 1 & $11 / 101(10.9 \%)$ & $9 / 42(21.4 \%)$ & \\
\hline & Not examined & $0 / 101(0.0 \%)$ & $59 / 101(58.4 \%)$ & \\
\hline \multirow[t]{5}{*}{ Visual acuity } & Normal & $6 / 101(5.9 \%)$ & $0 / 42(0.0 \%)$ & 0.1101 \\
\hline & Grade 3 & $2 / 101(2.0 \%)$ & $0 / 42(0.0 \%)$ & 0.3576 \\
\hline & Grade 2 & 0/101 (0.0\%) & $0 / 42(0.0 \%)$ & \\
\hline & Grade 1 & 93/101 (92.1\%) & $42 / 42(100.0 \%)$ & \\
\hline & Not examined & $0 / 101(0.0 \%)$ & $59 / 101(58.4 \%)$ & \\
\hline
\end{tabular}

the purpose of this treatment is to inhibit progression of the disease and of functional eye disorders as well as improvement of patient's appearance [11, 36, 73]. Diagnostic criteria, selection of the treatment method as well as Graves ophthalmopathy treatment results are still the matter of controversy $[12,18,22,25,38,48,51,57,63,64]$.
Diagnosis is based mainly on clinical data $[4,12,33,54$, $62,64]$. In the analysed material, the most common complaints (most $95 \%$ of patients) were related to exophthalmos and in $75 \%$ of patients $(89 / 121)$ ocular symptoms were accompanied by hyperthyreosis. In the remaining $25 \%$ of patients, orbital CT scan was necessary to explain the

Table 4 Treatment results as assessed by computed tomography (CT) of the retrobulbar areas in the group of patients treated previously with intravenous steroid therapy $(n=101)$

Left eye after treatment completion —improvement
Right eye after treatment completion-improvement

Thickness of the superior rectus muscle

Thickness of the inferior rectus muscle

Thickness of the lateral rectus muscle

Thickness of the median rectus muscle

Fat tissue

Optic nerve

Lacrimal gland

$$
\begin{array}{r}
0 / 43(0.0 \%) \\
0 / 54(0.0 \%) \\
0 / 33(0.0 \%) \\
0 / 71(0.0 \%) \\
1 / 21(4.8 \%) \\
0 / 1(0.0 \%) \\
0 / 1(0.0 \%)
\end{array}
$$

$0 / 43(0.0 \%)$
$0 / 48(0.0 \%)$
$0 / 28(0.0 \%)$
$0 / 68(0.0 \%)$
$0 / 18(0.0 \%)$
$0 / 0(0.0 \%)$
$0 / 2(0.0 \%)$

numerator the number of patients with improvement, denominator the number of patients with particular symptoms at baseline 
Table 5 Treatment results as assessed by ophthalmologic examination in the group of patients treated with steroids and full-dose radiotherapy $20 \mathrm{~Gy} / 10$ fractions $(n=93)$ - the right eye

\begin{tabular}{|c|c|c|c|c|}
\hline & NOSPECT & Right eye before treatment & Right eye 12 months after treatment & $\mathrm{p}$ (Mc Nemara) \\
\hline \multirow[t]{5}{*}{ Exophthalmos } & Normal & $42 / 93(45.2 \%)$ & $42 / 87(48.3 \%)$ & 0.2561 \\
\hline & Grade 3 & $2 / 93(2.1 \%)$ & $0 / 87(0.0 \%)$ & \\
\hline & Grade 2 & $11 / 93(11.8 \%)$ & $12 / 87(13.8 \%)$ & \\
\hline & Grade 1 & $38 / 93(40.9 \%)$ & $33 / 87(37.9 \%)$ & \\
\hline & Not examined & $0 / 93(0.0 \%)$ & $6 / 93(6.45 \%)$ & \\
\hline \multirow[t]{5}{*}{ Soft tissues } & Normal & $14 / 93(15.1 \%)$ & $48 / 83(57.8 \%)$ & 0.1945 \\
\hline & Grade 3 & $1 / 93(1.1 \%)$ & $0 / 83(0.0 \%)$ & \\
\hline & Grade 2 & $30 / 93(32.3 \%)$ & $2 / 83(2.4 \%)$ & \\
\hline & Grade 1 & $47 / 93(50.5 \%)$ & $33 / 83(39.8 \%)$ & \\
\hline & Not examined & $0 / 93(0.0 \%)$ & $10 / 93(10.8 \%)$ & \\
\hline \multirow[t]{5}{*}{ Oculomotor muscles } & Normal & $21 / 93(22.6 \%)$ & $43 / 83(46.2 \%)$ & 0.8200 \\
\hline & Grade 3 & $6 / 93(6.4 \%)$ & $0 / 83(0.0 \%)$ & \\
\hline & Grade 2 & $33 / 93(35.5 \%)$ & $4 / 83(4.3 \%)$ & \\
\hline & Grade 1 & $34 / 93(36.6 \%)$ & $36 / 83(38.7 \%)$ & \\
\hline & Not examined & $0 / 93(0.0 \%)$ & $10 / 93(10.8 \%)$ & \\
\hline \multirow[t]{5}{*}{ Cornea } & Normal & $80 / 93(86.0 \%)$ & $79 / 83(95.2 \%)$ & 0.8816 \\
\hline & Grade 3 & $0 / 93(0.0 \%)$ & $0 / 83(0.0 \%)$ & \\
\hline & Grade 2 & $0 / 93(0.0 \%)$ & $0 / 83(0.0 \%)$ & \\
\hline & Grade 1 & $13 / 93(14.0 \%)$ & $4 / 83(4.8 \%)$ & \\
\hline & Not examined & $0 / 93(0.0 \%)$ & $10 / 93(10.8 \%)$ & \\
\hline \multirow[t]{5}{*}{ Visual acuity } & Normal & $7 / 93(7.5 \%)$ & $4 / 83(4.8 \%)$ & 0.1046 \\
\hline & Grade 3 & $0 / 93(0.0 \%)$ & $0 / 83(0.0 \%)$ & \\
\hline & Grade 2 & $0 / 93(0.0 \%)$ & $0 / 83(0.0 \%)$ & \\
\hline & Grade 1 & $86 / 93(92.5 \%)$ & $79 / 83(95.2 \%)$ & \\
\hline & Not examined & $0 / 93(0.0 \%)$ & $10 / 93(10.8 \%)$ & \\
\hline
\end{tabular}

cause of ocular symptoms. The most important for diagnosis of Graves ophthalmopathy is evaluation of the oculomotor muscles diameters with maximum normal values of $4.9 \mathrm{~mm}(-/+0.5 \mathrm{~mm})$ [64].

The decision concerning the treatment of malignant exophthalmos must be based on assessment of two elements: severity of the symptoms and the level of disease control $[3,11]$. An obvious reflection of disease severity is a significantly limited field of vision related to infiltration of the optic nerve, as well as significant exophthalmos [11]. A separate problem is the level of disease activity. It seems that after a period of progression, malignant exophthalmos enters the phase of partial remission followed by a stationary period. Additionally, exophthalmos activity level does not correlate with symptoms severity [11].

Glycocorticosteroids may be used in the oral (prednisone), retrobulbar/subconjunctival or intravenous (methylprednisolone acetate) forms $[11,29,44,64,73]$. The intravenous route seems to be the most effective one, particularly with respect to the soft tissue symptoms and optic neuropathy [9-11]. The effect of steroid therapy on exophthalmos and eye globe mobility is only a minor one [11]. Improvement is found in about $60 \%$ of patients with infiltrative ophthalmopathy $[11,64,73]$. Additionally, this treatment is associated with numerous side effects [11, 26, 29, 42, 44, 51, 53, 73].

The efficacy of radiotherapy alone in the treatment of Graves ophthalmopathy is assessed to be about $60 \%[6,20$, $27,30,57,58,62,64,73]$. In the discussed material, only five patients were treated with radiotherapy alone. The above treatment was mostly effective in elimination of eye burning sensation and lacrimation, peribulbar tissue oedema and pain and/or eye pushing-out sensation. The follow-up ophthalmologic examination suggests improvement of vision acuity and $\mathrm{CT}$ scan, improvement of optic nerve condition. It could be accordant with literature data but the relatively low number of the observed patients makes it difficult to draw any conclusions [2, 19, 50].

In the discussed material, acute reaction to radiotherapy occurred in $11 / 121$ patients $(9.1 \%)$ and it was transient in nature. Radiation sequent reported in the literature such as: palpebral erythema, periorbital and conjunctival oedema, 
Table 6 Treatment results as assessed by ophthalmologic examination in the group of patients treated with steroids and full-dose radiotherapy $20 \mathrm{~Gy} / 10$ fractions $(n=93)$ - the left eye

\begin{tabular}{|c|c|c|c|c|}
\hline & NOSPECT & Left eye before treatment & Left eye 12 months after treatment & $\mathrm{p}$ (Mc Nemara) \\
\hline \multirow[t]{5}{*}{ Exophthalmos } & Normal & $49 / 93(52.7 \%)$ & $48 / 86(55.8 \%)$ & 0.0698 \\
\hline & Grade 3 & $3 / 93(3.2 \%)$ & $0 / 86(0.0 \%)$ & \\
\hline & Grade 2 & $12 / 93(12.9 \%)$ & $6 / 86(7.0 \%)$ & \\
\hline & Grade 1 & $29 / 93(31.2 \%)$ & $32 / 86(37.2 \%)$ & \\
\hline & Not examined & $0 / 93(0.0 \%)$ & $7 / 93(7.5 \%)$ & \\
\hline \multirow[t]{5}{*}{ Soft tissues } & Normal & $14 / 93(15.0 \%)$ & $41 / 74(55.4 \%)$ & 0.2942 \\
\hline & Grade 3 & $1 / 93(1.1 \%)$ & $0 / 74(0.0 \%)$ & \\
\hline & Grade 2 & $29 / 93(31.2 \%)$ & $1 / 74(1.4 \%)$ & \\
\hline & Grade 1 & $49 / 93(52.7 \%)$ & $32 / 74(43.2 \%)$ & \\
\hline & Not examined & $0 / 93(0.0 \%)$ & $19 / 93(20.4 \%)$ & \\
\hline \multirow[t]{5}{*}{ Oculomotor muscles } & Normal & $15 / 93(16.1 \%)$ & $35 / 83(42.2 \%)$ & 0.3332 \\
\hline & Grade 3 & $5 / 93(5.4 \%)$ & $0 / 83(0.0 \%)$ & \\
\hline & Grade 2 & $32 / 93(34.4 \%)$ & $5 / 83(6.0 \%)$ & \\
\hline & Grade 1 & $41 / 93(44.1 \%)$ & $43 / 83(51.8 \%)$ & \\
\hline & Not examined & $0 / 93(0.0 \%)$ & $10 / 93(10.8 \%)$ & \\
\hline \multirow[t]{5}{*}{ Cornea } & Normal & $80 / 93(86.0 \%)$ & $76 / 82(92.7 \%)$ & 0.8216 \\
\hline & Grade 3 & $1 / 93(1.1 \%)$ & $0 / 82(0.0 \%)$ & \\
\hline & Grade 2 & $1 / 93(1.1 \%)$ & $0 / 82(0.0 \%)$ & \\
\hline & Grade 1 & $11 / 93(11.8 \%)$ & $6 / 82(7.3 \%)$ & \\
\hline & Not examined & $0 / 93(0.0 \%)$ & $11 / 93(11.8 \%)$ & \\
\hline \multirow[t]{5}{*}{ Visual acuity } & Normal & $6 / 93(6.4 \%)$ & $5 / 83(6.0 \%)$ & 0.1696 \\
\hline & Grade 3 & $1 / 93(1.1 \%)$ & $1 / 83(1.2 \%)$ & 0.9700 \\
\hline & Grade 2 & $0 / 93(0.0 \%)$ & $0 / 83(0.0 \%)$ & \\
\hline & Grade 1 & $86 / 93(92.5 \%)$ & 77/83 (92.8\%) & \\
\hline & Not examined & $0 / 93(0.0 \%)$ & $10 / 93(10.7 \%)$ & \\
\hline
\end{tabular}

headache, hair loss, blurred vision were also transient and mild in nature [14, 17, 34, 47, 52, 55, 60, 65, 73, 74].

Late complications following radiotherapy of retrobulbar area include: retinopathy, cataract and radiation-induced tumours $[9,13-15,17,23,24,26,29,42,43,45,46,51$, $59,61,65,66,68,73]$. In the presented material, three cases of cataract (three out of $106=2.8 \%$ ) were reported that however might have been related to the physiological ageing process and not to radiotherapy. In the group of diabetic patients $(12 / 93=12.9 \%)$ no diabetic retinopathy was found after the combined treatment. Until now, no secondary tumours were found within the previously irradiated area.

At least two controlled studies showed that combination of high-dose steroid therapy with radiotherapy is the most

Table 7 Treatment results as assessed by computed tomography (CT) of the retrobulbar areas in the group of patients treated with steroids and full-dose radiotherapy $20 \mathrm{~Gy} / 10$ fractions $(n=93)$

Left eye after treatment completion-improvement
Right eye after treatment completion-improvement

Thickness of the superior rectus muscle thickness of the inferior rectus muscle Thickness of the lateral rectus muscle Thickness of the median rectus muscle

Fat tissue

Optic nerve Lacrimal gland

$$
\begin{gathered}
0 / 41(0.0 \%) \\
0 / 51(0.0 \%) \\
0 / 30(0.0 \%) \\
0 / 68(0.0 \%) \\
2 / 21(9.5 \%) \\
1 / 1(100 \%) \\
0 / 1(0.0 \%)
\end{gathered}
$$

$0 / 41(0.0 \%)$

$0 / 45(0.0 \%)$

$0 / 26(0.0 \%)$

$0 / 63(0.0 \%)$

$0 / 18(0.0 \%)$

$0 / 0(0.0 \%)$

$0 / 2(0.0 \%)$

numerator the number of patients with improvement, denominator the number of patients with particular symptoms before the treatment 
Table 8 Patient self-reported eye symptoms improvement by treatment method

\begin{tabular}{|c|c|c|c|}
\hline Symptom & $\begin{array}{l}\text { Steroid therapy } n=101 \\
\text { A }\end{array}$ & $\begin{array}{l}\text { Combined therapy } n=93 \\
\text { B }\end{array}$ & $\mathrm{p}$ (Fisher test) \\
\hline Unilateral or bilateral exophthalmos & $49 / 97(50.5 \%)$ & $71 / 89(79.8 \%)$ & $\mathrm{A} / \mathrm{B} 0.0000$ \\
\hline Oedema of the peribulbar soft tissue & $39 / 96(40.6 \%)$ & $56 / 88(63.7 \%)$ & $\mathrm{A} / \mathrm{B} 0.0020$ \\
\hline Diplopia & $50 / 93(53.8 \%)$ & $47 / 85(55.3 \%)$ & A/B 0.8809 \\
\hline Eye burning/lacrimation & $35 / 91(38.5 \%)$ & $61 / 84(72.6 \%)$ & $\mathrm{A} / \mathrm{B} 0.0000$ \\
\hline Pain and/or eye pushing-out sensation & $27 / 81(33.3 \%)$ & $56 / 76(73.7 \%)$ & $\mathrm{A} / \mathrm{B} 0.0000$ \\
\hline Visual acuity & $26 / 50(52.0 \%)$ & $26 / 47(55.3 \%)$ & $\mathrm{A} / \mathrm{B} 0.8392$ \\
\hline Colour vision & $4 / 7(57.1 \%)$ & $5 / 6(83.3 \%)$ & $\mathrm{A} / \mathrm{B} 0.5594$ \\
\hline
\end{tabular}

numerator the number of patients with improvement, denominator the number of patients reporting particular symptoms at baseline

Table 9 Improvement of ocular symptoms by sex in the group of patients treated with the combined method $(n=93)$

numerator the number of patients with improvement, denominator the number of patients (by sex) with particular symptoms at baseline

${ }^{\text {a }}$ Statistically significant difference $(p<0.05)$

\begin{tabular}{lccc}
\hline Symptom & Men improvement & Women improvement & Chi square \\
\hline Exophthalmos & $16 / 22(72.7 \%)$ & $54 / 67(80.6 \%)$ & 0.4345 \\
Oedema & $15 / 22(68.2 \%)$ & $40 / 66(60.6 \%)$ & 0.5250 \\
Diplopia & $8 / 22(36.4 \%)$ & $38 / 63(60.3 \%)$ & 0.0523 \\
Eye burning/tearing & $10 / 20(50.0 \%)$ & $50 / 64(78.1 \%)$ & $0.0151^{\mathrm{a}}$ \\
Pain/eye pushing-out sensation & $13 / 17(76.5 \%)$ & $41 / 58(70.7 \%)$ & 0.6406 \\
Visual acuity & $4 / 12(33.3 \%)$ & $22 / 35(62.8 \%)$ & 0.0759 \\
Colour vision & $0 / 0(0.0 \%)$ & $5 / 5(100 \%)$ & \\
\hline
\end{tabular}

Table 10 Improvement of ocular symptoms in diabetic and non-diabetic patients in the group treated with the combined method $(n=93)$

\begin{tabular}{lccc}
\hline Symptom & Diabetics improvement & Non-diabetics improvement & Chi square \\
\hline Exophthalmos & $6 / 11(54.6 \%)$ & $65 / 78(83.3 \%)$ & $0.0261^{\mathrm{a}}$ \\
Oedema & $6 / 12(50.0 \%)$ & $50 / 76(65.8 \%)$ & 0.2907 \\
Diplopia & $2 / 11(18.2 \%)$ & $44 / 73(60.3 \%)$ & $0.0089^{\mathrm{a}}$ \\
Eye burning/tearing & $5 / 12(41.7 \%)$ & $56 / 72(77.8 \%)$ & $0.0094^{\mathrm{a}}$ \\
Pain/eye pushing-out sensation & $5 / 9(55.6 \%)$ & $51 / 67(76.1 \%)$ & 0.1884 \\
Visual acuity & $3 / 6(50.0 \%)$ & $23 / 41(56.1 \%)$ & 0.7790 \\
Colour vision & $1 / 2(50.0 \%)$ & $4 / 4(100 \%)$ & 0.1213 \\
\hline
\end{tabular}

numerator the number of patients with improvement, denominator the number of non-diabetics/diabetics with particular symptoms

${ }^{a}$ Statistically significant difference $(p<0.05)$

Table 11 Symptoms of acute reaction in the group of 121 patients with Graves ophthalmopathy occurring during radiotherapy of retrobulbar areas

\begin{tabular}{ll}
\hline Acute post-irradiation reaction & $\mathrm{n}=121$ \\
\hline Significant tearing and eyelid oedema & $3(2.5 \%)$ \\
Erythema in high-dose areas & $3(2.5 \%)$ \\
Slight tearing & $2(1.6 \%)$ \\
Erythema and eye burning sensation & $1(0.8 \%)$ \\
Aggravation of diplopia and worsening of visual acuity & $1(0.8 \%)$ \\
Aggravation of tearing and worsening of visual acuity & $1(0.8 \%)$ \\
\hline
\end{tabular}

Table 12 Symptoms of late post-irradiation reaction found during follow-up after treatment completion in the group of 101 patients with Graves ophthalmopathy

\begin{tabular}{ll}
\hline Late post-irradiation reaction & $\mathrm{n}=101$ \\
\hline Retinopathy & $0(0.0 \%)$ \\
Cataract & $3(2.8 \%)$ \\
Radiation-induced tumours & $0(0.0 \%)$
\end{tabular}


effective treatment of malignant exophthalmos [5, 11, 41, 75]. In the analysed material, the vast majority of patients were treated with the combined method (93/101). Based on the follow-up ophthalmologic examination, it was shown the intravenous steroid therapy followed by radiotherapy is effective with respect to normalisation of soft tissue and oculomotor muscles condition as well as exophthalmos improvement.

The following factors are considered to worsen the prognosis of ophthalmopathy: patient age above 5060 years, male sex, smoking, symptom duration, concomitant diabetes, hyperthyreosis $[2,5,8,9,13,14,25,26,30$, $32,45,49,51,52,58,59,70]$. The effect of these factors was analysed in the group of patients treated with the most effective method, i.e. with the combined method. Patient age, symptom duration, smoking, TSH and fT4 levels did not affect significantly the results of the malignant exophthalmos treatment - in contrast to concomitant diabetes and male sex.

Graves ophthalmopathy treatment available at present is not fully satisfactory. Its efficacy is assessed to be about $60-80 \%[46,51]$. Therefore, new treatment methods are tested. Use of cytokine antagonists, in particular, penthoxiphyline, somatostatin analogues and colchicine seems to be the most promising among them $[10,36,64,73]$.

However, the majority of centres consider combined steroid and radiotherapy treatment to be, at present, the best treatment method for Graves ophthalmopathy $[31,57,64$, $67,73,75]$.

\section{Conclusions}

1. Radiotherapy combined with steroid therapy in the treatment of Graves ophthalmopathy seems to be an effective treatment of malignant exophthalmos symptoms at strictly defined indications.

2. Radiotherapy is a well-tolerated treatment modality in Graves ophthalmopathy.

3. Diabetes mellitus is a factor worsening prognosis in Graves ophthalmopathy.

4. Female sex is a favourable prognostic factor in Graves ophthalmopathy.

Conflict of interest statement There is no conflict of interest related to this paper.

Open Access This article is distributed under the terms of the Creative Commons Attribution Noncommercial License which permits any noncommercial use, distribution, and reproduction in any medium, provided the original author(s) and source are credited.

\section{References}

1. Abalkhail S, Doi SA, Al-Shoumer KA. The use of corticosteroids versus other treatment for Graves ophthalmopathy: a quantitative evaluation. Med Sci Monit. 2003;9:477-83.

2. Alpert TE, Alpert SG, Bersani TA, Hahn SS, Bogart JA, Chung CT. Radiotherapy for moderate-to-severe Graves ophthalmopathy: improved outcomes with early treatment. Cancer J. 2003;9:472-5.

3. Asman P. Ophthalmological evaluation in thyroid-associated ophthalmopathy. Acta Ophthalmol Scan. 2003;81:437-43.

4. Bahn RS, Heufelder AE. Pathogenesis of Graves ophthalmopathy. NEJM. 1993;329:1468-75.

5. Bartalena L, Marcocci C, Chiovato L, Laddage M, Lepri G, Andreani $\mathrm{D}$, et al. Orbital cobalt irradiation combined with systemic corticosteroids for Graves ophthalmopathy: comparison with systemic corticosteroids alone. J Clin Endocrinol Metab. 1983;56:1139-44.

6. Bartalena L, Marcocci C, Gorman CA, Wiersinga WM, Pinchera A. Orbital radiotherapy for Graves ophthalmopathy: useful or useless? Safe or dangerous? J Endocrinol Invest. 2003;26:5-161.

7. Bartalena L, Marcocci C, Pinchera A. Treating severe Graves ophthalmopathy. Baillieres Clin Endocinol Metab. 1997;11:521-36.

8. Bartalena L, Marcocci C, Tanda ML, Manetti L, Dell Unto E, Bartolomei MP, et al. et al. Cigarette smoking and treatment outcomes in Graves ophthalmopathy. Ann Intern Med. 1998;129(8):632-5.

9. Bartalena L, Marcocci C, Tanda ML, Rocchi R, Mazzi B, Barbesino G, et al. Orbital radiotherapy for Graves ophthalmopathy. Thyroid. 2002;12:245-50.

10. Bartalena L, Martino E, Marcocci C, Bogazzi F, Panicucci M, Velluzzi F, et al. More on smoking habits and Graves ophthalmopathy. J Endocrinol Invest. 1989;12:733-7.

11. Bartalena L, Pinchera A, Marccoci C. Management of Graves ophthalmopathy: reality and perspectives. Endocr Rev. 2000;21: 168-99.

12. Bartley GB, Gorman CA. Diagnostic criteria for Graves ophthalmopathy. Am J Ophthalmol. 1995;119:792-5.

13. Beckendorf V, Maalouf T, George JL, Bey P, Leclere J, Luporsi E. Place of radiotherapy in the treatment of Graves orbitopathy. Int J Radiation Oncology Biol Phys. 1999;43:805-15.

14. Brennan MW, Leone CR Jr, Janaki L. Radiation therapy for Graves disease. Am J Ophtahmol. 1983;96:195-9.

15. Broerse JJ, Snijders-Keilholz A, Jansen JTM, Zoetelief J, Klein C, Seegenschmiedt MH. Assessment of carcinogenic risk for treatment of Graves ophthalmopathy in dependence on age and irradiation geometry. Radiother Oncol. 1999;53:205-8.

16. Burch HB, Wartofsky L. Graves ophthalmopathy: current concepted regarding pathogenesis and management. Endocrine Reviews. 1993;14:747-93.

17. McDougall R, Donaldson SS. Radiotherapy for Graves ophthalmopathy: current treatment recommendations. Front Radiat Ther Oncol. 2001;35:57-64.

18. Feldon SE. Radiation therapy for Graves ophthalmopathy: trick or treat? Ophthalmology. 2001;108:1521-2.

19. Feldon SE, Lee CP, Muramatsu SK, Weiner JM. Quantitative computed tomography of Graves ophthalmopathy. Arch Ophthalmol. 1985; 103:213-5.

20. Gerling J, Kommerell G, Henne K, Laubenberger J, SchulteMonting J, Fells P. Retrobulbar irradiation for thyroid-associated orbitopathy: double blind comparison between 2,4 and 16 Gy. Int J Rad Oncol Biol Phys. 2003;55:182-9.

21. Glatt HJ. Optic nerve dysfunction in thyroid eye disease: a clinician's perspective. Radiology. 1996;200:26-7.

22. Gorman CA. The measurement of change in Graves ophthalmopathy. Thyroid. 1998;8:539-43.

23. Gorman CA. Radiotherapy for Graves ophthalmopathy: results one year. Thyroid. 2002;12:251-5. 
24. Gorman CA, Garrity JA, Fatourechi V, Bahn RS, Petersen IA, Stafford SL, et al. A prospective, randomized, double - blind, placebo-controlled study of orbital radiotherapy for Graves ophthalmopathy. Ophthalmopathy. 2001;108:1523-34.

25. Gorman CA, Garrity JA, Fatourechi V, Bahn RS, Petersen IA, Stafford SL, et al. The aftermath of orbital radiotherapy for Graves ophthalmopathy. Ophthalmology. 2002;109:2100-7.

26. de Groot JL, Gorman CA, Pinchera A, Bartalena L, Marocci C, Wiersinga WM, et al. Therapeutic controversies: radiation and Graves ophthalmopathy. J Clin Endocrinol Metab. 1995;80:339-49.

27. Hurbli T, Char DH, Harris J, Weaver K, Greenspan F, Sheline G. Radiation therapy for thyroid eye disease. Am J Ophthalmol. 1985;99:633-7.

28. Janik J, Jastrzębska H, Gietka-Czernel M, Zgliczyński S, Rożniatowska B, Elbanowski J. Zmiany oczne u pacjentów z chorobą Gravesa przebiegającą z eutyreozą. Okulistyka (Suplement). 2003;1:153-6.

29. Jastrzębska H, Gietka-Czernel M, Janik J, Zgliczyński S, Karczmarzyk R, Fijuth J, et al. Kortykoterapia, radioterapia i leczenie chirurgiczne - trzy kolejne etapy standardowego leczenia 960 chorych z ciężką oftalmopatią Gravesa. Endokrynologia Polska. 2004;3:245-62.

30. Jaulerry C. The role of radiotherapy in Graves ophthalmopathy. J Fr Ophtalmol. 2004;27:825-7.

31. Kao SCS, Kendler DL, Nugent RA, Adler JA, Rootman J. Radiotherapy in the management of thyroid ophthalmopathy. Arch Ophthalmol. 1993;111:819-23.

32. Kendall-Taylor P. Current management of thyroid-associated ophthalmopathy. Commentary. Clin Endocrinol. 1998;49:11-2.

33. Kendler DL, Lippa J, Rootman J. The initial clinical characteristics of Graves orbitopathy vary with age and sex. Arch Ophtalmol. 1993;111:197-201.

34. Kinyoun JL, Kalina RE, Brower SA, Mills RP, Johnson RH. Radiation retinopathy after orbital irradiation for Graves ophthalmopathy. Arch Ophthalmol. 1984;102:1473-6.

35. Koshiyama H, Koh T, Fujiwara K, Hayakawa K, Shimbo S, Misaki T. Therapy of Graves ophthalmopathy with intravenous high-dose steroid followed by orbital irradiation. Thyroid. 1994;4:409-13.

36. Kraus DJ. Management of thyroid ophthalmopathy. Curr Opin Ophthalmol. 1996;7:54-9.

37. Kuhnt T, Muller AC, Janich M, Gerlach R, Hadecke J, Duncker GI, et al. Radiotherapy for Graves ophthalmopathy. Klin Monatsbl Augenheilkd. 2004;221:915-21.

38. Leer JW, van Houtte P, Seegenschmiedt H. Radiotherapy of nonmalignant disorders: where do we stand? Radioth Oncol. 2007;83:175-7.

39. Lloyd WC III, Leone CR Jr. Supervoltage orbital radiotherapy in 36 cases of Graves disease. Am J Ophthalmol. 1992;113:374-80.

40. Mackiewicz E. Porównanie metod leczenia oftalmopatii towarzyszącej chorobie Gravesa-Basedowa. Okulistyka. 2002;1:35-9.

41. Marccoci C, Bartalena L, Bogazzi F, Bruno-Bossio G, Lepri A, Pinchera A. Orbital radiotherapy combined with high dose systemic glucocorticoids for Graves ophthalmopathy is more effective than orbital radiotherapy alone: results of a prospective randomized study. J Endocrinol Invest. 1991;14:853-60.

42. Marcocci C, Bartalena L, Bruno-Bossio G, Vanni G, Cartei F, Bogazzi F, et al. Orbital radiotherapy in the treatment of endocrine ophthalmopathy: when and why? Endocrine ophthalmopathy. Molecular, immunological and clinical aspects. Dev Ophthalmol. 1993;25:131-41.

43. Marcocci C, Bartalena L, Rocchi R, Marino M, Menconi F, Morabito $\mathrm{E}$, et al. Long-term safety of orbital radiotherapy for Graves ophthalmopathy. J Clin Endocrinol Metab. 2003;88:3561-6.

44. Marccoci C, Bartalena L, Tanda ML, Manetti L, Dell Unto E, Rocchi R, et al. Comparison of the effectiveness and tolerability of intravenous or oral glucocorticoids associated with orbital radiotherapy in the management of severe Graves ophthalmopathy: results of a prospective, single-blind randomized study. J Clin Endocrin Metab. 2001;86:3562-7.

45. Marquez SD, Lum BL, McDougall IR, Katkuri S, Levin PS, McManus M, et al. Long- term results of irradiation for patients with progressive Graves ophthalmopathy. Int J Radiat Oncol Biol Phys. 2001;51:766-74.

46. Miller ML, Goldberg SH, Bullock JD. Radiation retinopathy after standard radiotherapy for thyroid-related ophthalmopathy. Am J Ophthalmol. 1991;112:600-601.

47. Mourits MP, van Kempen-Harteveld ML, Garcia Garcia MB, Koppeschaar HPF, Tick L, Terwee CB. Radiotherapy for Graves orbitopathy: randomized placebo-controlled study. Lancet. 2000; 355:1505-9.

48. Mourits MP, Koorneef L, Wiersinga WM, Prummel MF, Berghout A, van der Gaag R. Clinical criteria for the assessment of disease activity in Graves ophthalmopathy: a novel approach. $\mathrm{Br} \mathrm{J}$ Ophthalmol. 1989;73:639-44.

49. Noth D, Gebauer M, Muller B, Burgi U, Diem P. Graves ophthalmopathy: natural history and treatment outcomes. Swiss Med Wkly. 2001;20(131):41-2.

50. Nugent RA, Belkin RI, Neigel JM, Rootman J, Robertson WD, Spinelli J, et al. Graves orbitopathy: correlation of CT and clinical findings. Radiology. 1990;177:675-82.

51. Ohtsuka K, Sato A, Kawaguchi S, Hashimoto M, Suzuki Y. Effect of steroid pulse therapy with and without orbital radiotherapy on Graves ophthalmopathy. Am J Ophthalmol. 2003;135:285-90.

52. Olivotto IA, Ludgate CM, Allen LH, Rootman J. Supervoltage radiotherapy for Graves ophthalmopathy: CCABC technique and results. Int J Radiat Oncol Biol Phys. 1985;11:2085-90.

53. van Ouwerkerk BM, Wijngaarde R, Hennemann G. Radiotherapy of severe ophthalmic Graves disease. J Endocrinol Invest. 1985;8: $241-7$.

54. Ozgen A, Alp MN, Ariyurek M, Tutuncu NB, Can I, Gunalp I. Quantitative CT of the orbit in Graves disease. Br J Radiol. 1999;72:757-62.

55. Palmer D, Greenberg P, Cornell P, Parker RG. Radiation therapy for Graves ophthalmopathy: a retrospective analysis. Int J Rad Oncol Biol Phys. 1987;13:1815-20.

56. Perez CA, Brady LW, Halperin EC, Schmidt-Ulrich RK. Principles and practice of radiation oncology. Radiation treatment of benign disease. 2004: 2333-4.

57. Pilarska K, Czekalski S, Syrewicz A, Andrzejewska W, Krzysztolik Z, Przerwa D, et al. Ocena współczesnych wyników skojarzonego leczenia glukokortykoidami i teleradioterapią postępującej oftalmopatii obrzękowo-naciekowej w chorobie Graves- Basedowa. Endokrynol Pol. 1991;42:379-87.

58. Prummel MF, Mourits MP, Blank L, Berghout A, Koornneef L, Wiersinga WM. Randomized double-blind trial of prednisone versus radiotherapy in Graves ophthalmopathy. Lancet. 1993;342: 949-54.

59. Sakata K, Hareyama M, Oouchi A, Shidou M, Nagakura H, Morita K, et al. Radiotherapy in the management of Graves ophthalmopathy. Jpn J Clin Oncol. 1998;28:364-7.

60. Sandler HM, Rubenstein JH, Fowble BL, Sergott RC, Savino PJ, Bosley TM. Results of radiotherapy for thyroid ophthalmopathy. Int J Radiation Oncology Biol Phys. 1989;17:823-827.

61. Schaefer U, Hesselmann S, Micke O, Schueller P, Bruns F, Palma C, et al. A long-term follow-up study after retro-orbital irradiation for Grave ophthalmopathy. Int J Radiat Oncol Biol Phys. 2002;52:192-7.

62. Seegenschmiedt MH, Heyd R, Esser J, Mould RF. Choroba Gravesa ze szczególnym uwzględnieniem roli radioterapii. Nowotwory. 2006;56:537-44.

63. Seegenschmiedt MH, Keilholz L, Gusek-Schneider G, Bart S, Hensen J, Wolf F, et al. Endocrine orbitopathy: comparison of the long-term results and classification after radiotherapy. Strahlenther Onkol. 1998;174:449-56. 
64. Siewko K, Szelachowska M, Topolska J, Myśliwiec J, Kinalska I. Oftalmopatia Gravesa-aktualne poglądy na diagnostykę i leczenie. Endokrynol Pol. 2001;52(2):293-302.

65. Smitt MC, Donaldson SS. Radiation therapy for benign disease of the orbit. Sem Rad Oncol. 1999;9:179-89.

66. Snijders-Keilholz A, De Keizer RJW, Goslings BM, van Dam EWCM, Jansen JTM, Broerse JJ. Probable risk of tumour induction after retro-orbital irradiation for Graves ophthalmopathy. Radioth Oncol. 1996;38:69-71.

67. Tsujino K, Hirota S, Hagiwara M, Fukada S, Tadaka Y, Hishikawa $\mathrm{Y}$, et al. Clinical outcomes of orbital irradiation combined with or without systemic high-dose or pulsed corticosteroids for Graves ophthalmopathy. Int J Radiat Oncol Biol Phys. 2000;48:857-64.

68. Wakelkamp IM, Tan H, Saeed P, Schlingemann RO, Verbraak FD, Blank LE, et al. Orbital irradiation for Graves ophthalmopathy: Is it safe? A long-term follow-up study. Ophthalmology. 2004;111:1557-62.
69. Weber AL, Dallow RL, Sabates NR. Graves disease of the orbit. Neuroimaging Clin N Am. 1996;6:61-72.

70. Wiersinga WM. Preventing Graves ophthalmopathy. NEJM. 1998;338:121-2.

71. Wiersinga WM. Retrobulbar irradiation in Graves orbitopathy: the Dutch experience. Ophthal Plast Reconstr Surg. 2002;18:175-6.

72. Wiersinga WM, Prummel MF. Graves ophthalmopathy: a rational approach to treatment. Trends Endocrinol Metab. 2002;13:280-7.

73. Wierzbowska J, Stankiewicz A. Patogeneza i leczenie oftalmopatii Gravesa. Klinika Oczna. 2002;104:147-153.

74. Yeatts RP. Graves ophthalmopathy. Med Clin North Am. 1995;79:195-209.

75. Zgliczyński S, Jastrzębska H, Górowski T, Janik J, Kuś J, Hliniak A, et al. Wyniki 3 - etapowego leczenia: (I) kortykoterapia, (II) akcelerator liniowy i (III) dekompresja oczodołów, 206 chorych z wytrzeszczem złośliwym w chorobie Graves- Basedowa. Endokrynol Pol. 1992;43:274-285. 